\title{
The Implementation of Make A Match Type Cooperative Learning Model to Improve the Mathematical Connection Ability
}

\author{
Maulidawati ${ }^{1, a}$, Iryana Muhammad ${ }^{1, b *}{\text { Rohantizani }{ }^{1, c}, \text { \& Mursalin }}^{1, d}$ \\ ${ }^{1}$ Department of Mathematics Education, Universitas Malikussaleh, Aceh Utara, Indonesia \\ a maulidawati1999@gmail.com; b iryana.muhammad@unimal.ac.id crohantizani@unimal.ac.id; \\ d mursalin@unimal.ac.id \\ *Corresponding Author : iryana.muhammad@unimal.ac.id [ Phone : +6285262807674 ]
}

\begin{abstract}
Mathematics is a discipline that is taught at every level of education in Indonesia. Mathematics are interrelated with each other, and cannot be separated from other disciplines and problems in everyday life. Process standards that students use in learning mathematics include problem solving, reasoning and proof, connection, communication, and representation. This study aims to determine the mathematical connection ability of students who are taught through the make a match cooperative learning model better than the students' mathematical connection ability through the scientific learning model on the line and row material in class XI SMAN 1 Pintu Rime Gayo. This research is a quasiexperimental study using the pretest-posttest group design. The samples taken were class XI MIA 2 as the experimental class and XI MIA 1 as the control class. Retrieval of data in research using tests. The data collected from the test results were analyzed using SPSS version 18 to find normality using the Shapiro-Wilk test and to test the hypothesis using the Mann-Whitney-Test. Based on the results of data analysis, it shows that the N-gain average score of students who apply the make a match cooperative learning model is 0.71 (high category), higher than students who use scientific learning of 0.36 (moderate category). From the results of the Mann-Whitney-Test above, the Asymp value is obtained. Sig (1-tailed) is $0.0005<$ a 0.05 . This shows that the increase in students' mathematical connection ability through cooperative learning type make a match is significantly better than students who get scientific learning.
\end{abstract}

Keywords: mathematical connection capability; cooperative learning model; make a match type; scientific learning;

\section{Introduction}

As a whole, humans are born having the ability to face problems that arise and deal with them. Intelligence as the basic concept of human resources is the key word for resolution. Quality human resources are a necessity that cannot be negotiated. The era of quality and quality in all areas of life to adjust the vision, mission and strategy as needed, as well as education. According to Sanjaya (2011: 2), "Education is a conscious and planned effort to create an atmosphere of learning and the learning process so that students can actively develop their potential to have religious spiritual strength, self-control, personality, intelligence, noble character, and the necessary skills. himself, the people of the nation and the state. " So education is one very important aspect of life, education at all levels is related to gaining knowledge, skills and attitudes. Basic education is the foundation as a guide to achieve good goals, both formal education and non-formal education. In the implementation of non-formal education, the learning process greatly determines the success of student learning. Therefore, the achievement of educational goals itself cannot be separated from the important role of the teaching and learning process experienced by students and educators during the learning process. Law No. 20 of 2013 concerning the National Education System Chapter II Article 3, Hendriana (2016: 6) states that the purpose of education is a conscious and planned effort to create an atmosphere of learning and the learning process so that students actively develop their potential to have spiritual power. religion, self-control, personality, intelligence, noble character, and skills needed by him, society, nation and state.

Mathematics is a discipline that is taught at every level of education in Indonesia. Mathematics are interrelated with each other, and cannot be separated from other scientific disciplines and problems in everyday life. According to NCTM (2000: 29), the standard processes used by students in learning 
mathematics include problem solving, reasoning and proof, connection, communication, and representation. The ability to explain the relationship between concepts is part of the mathematical connection ability. Mathematical connection is one of the standards of the mathematics learning process and if students are able to relate mathematical ideas, students are also able to improve their mathematical understanding and are able to see the linkages between mathematical ideas, with other disciplines, and also with experiences of everyday life.

Mathematical connection is the ability to relate mathematical concepts to other disciplines and also with everyday life that is often encountered. By having the mathematical connection capability, students will understand more easily and also learning mathematics will feel easier. But most of the students think that learning mathematics is just learning mathematical subjects which contain formulas and a number of numbers that make students bored in learning because students will only memorize/remember the concepts being taught. One of the materials in mathematics is for example the material of sequences and series. A sequence is an arrangement of numbers formed according to a certain order and the sequence is the sum of all terms of a sequence. The application of sequence and series material is not only in mathematics lessons but also in everyday life such as calculating income, using labor, etc.

Based on the results of observations at SMAN 1 Pintu Rime Gayo, the researcher got information that there are still many students who have difficulty learning mathematics, this is due to the lack of student interest in learning mathematics. This results in students becoming less understanding of mathematics, especially in solving math problems, let alone linking it in everyday life. They tend to record what is explained by the teacher without understanding the concept and in solving the questions only based on the example questions given and mathematics learning which is more centered on the teacher, students only receive information from the teacher, resulting in students being more passive and just listening to learning. In fact, the silence of the students during learning does not necessarily mean that they understand the lesson given. The following is one of the students' mathematical connection ability questions on the sequence and series material.

"Ali bought a sewing machine in 2013 for IDR 5,000,000. The machine experienced a 5\% decrease in price every year from the previous year. Determine the price of the machine in 2018? "

The following is one of the students' answers to the questions above.

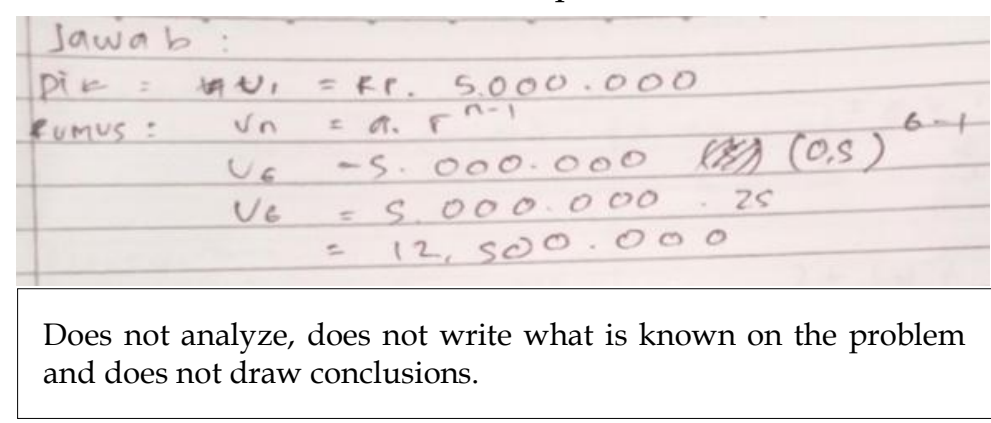

Figure 1. Analysis of Student Answers

The steps that students must take in solving the problem are identifying the problem, namely by looking at the information that is known in the questions, but from the analysis of the students' answers above, students do not write down what is known in the questions. This means that students have not been able to see the information that is known in the questions. Then the next step is to plan the completion, namely by writing the formula, the answer above proves that students can only choose information that is in accordance with the formula given by the teacher. Then in the step of solving the problem, namely by carrying out the calculation procedure and producing a solution, from the answers above, it can be seen that there are mistakes in solving the questions. In the last stage, students also do not draw conclusions from the problems given and cannot understand the relationship between mathematical topics in everyday life.

Haety and Mulyana (2013: 2) say that the ability of mathematical connections is important for students to master, but the problem that occurs is the ability of students to connect mathematically is still low. The results of the Program For International Student Assessment or PISA survey in 2009 (Organization for Economic Cooperation and Development or OECD in 2010) show that the percentage of secondary school students in Indonesia who are able to solve questions that require a connection process is only $5.4 \%$. This shows that $95 \%$ of students have not been able to associate several different representations of a mathematical concept both in mathematics itself and with everyday life. The low ability of students 'mathematical connections does not only come from the students' lack of ability, but there are factors that also determine the success of students in learning mathematics, namely learning that is tailored to the needs and situations of students, for example the selection of models or methods given in learning. 
The cooperative learning model make a match type is a learning model to find a partner. Make a match is a solution to improve students' mathematical connection skills. The cooperative learning model of the make a match type is a learning model developed by Lorna Curran in 1994, students must look for pairs of question cards they have while learning about a concept or topic in a pleasant atmosphere. In determining the answer card students are required to determine the answer or question from the card being held. Here there is interaction between groups and interactions between students in the group to discuss the questions and answers again so that by learning make a match can foster cooperation in answering questions in matching the cards in their hands, the learning process is more interesting and activeness is highly required to find a partner. card respectively. One of the advantages of this technique is that students find partners while learning about a concept or topic in a fun atmosphere. Based on the problems described, the researcher intends to conduct a study entitled "Application of the Make A Match Type Cooperative Learning Model in Improving the Mathematical Connection Ability of Class XI Students of SMAN 1 Pintu Rime Gayo."

\section{Research Methods}

This study uses a quantitative approach. According to Arikunto (2017: 27) "Quantitative research is research that is carried out using numbers, starting from data collection, data processing, interpretation of data and discussion of research results." While the type of research used by researchers is a quasi experimental design (quasi-experimental). According to Suryabrata (2013: 92) the objective of a quasi-experiment is to obtain information which is an estimate for the information that can be obtained by an actual experiment in situations where it is not possible to control and/or manipulate all relevant variables. This research design uses the prestest-posttest control group design. The prestest-posttest control group design study used two classes (control class and experimental class). In the experimental class, a pre-test was given to see the mathematical connection ability of students, after which the learning treatment was given using the cooperative model make a match. After completing the learning process, students are given a post-test to see the improvement in students' mathematical connection skills. Likewise in the control class, before the material is taught, a pretest will also be given. After the learning process takes place, a posttest is given to see the progress obtained. Thus, the experimental design in this study uses the prestest-posttest control group design by Sugiyono (2017: 112) which can be seen at table 1 .

Table 1. Research Design

\begin{tabular}{|c|c|c|c|}
\hline Treatment Class & Pretest & Treatment & Posttest \\
\hline Experiment & $\mathrm{O}_{1}$ & $X_{1}$ & $\mathrm{O}_{2}$ \\
\hline Control & $\mathrm{O}_{1}$ & - & $\mathrm{O}_{2}$ \\
\hline
\end{tabular}

Information:

O1: Pretest for the Make a Match model class

O1: Pretest for scientific class

X1: Make a Match learning treatment

O2: Postest for the Make a Match model class

O2: Postest for scientific class

This study was conducted at SMAN 1 Pintu Rime Gayo which is located at Jalan Bireun-Takengon, Blang Ara Village, Pintu Rime Gayo District, Bener Meriah Regency, Aceh Province. The choice of this school as a research location was due to several reasons, including the following:

1. Research has never been carried out with the cooperative learning model type make a match

2. This school is open to conducting research.

3. There is support from teachers at SMAN 1 Pintu Rime Gayo to conduct research on line and series materials with the make a match learning model.

This study was conducted in class XI of SMAN 1 Pintu Rime Gayo, which was studied in the even semester of the 2019/2020 school year.

The population in this study were students of class XI SMAN 1 Pintu Rime Gayo and the samples taken were XI MIA 2 as the experimental class and XI MIA 1 as the control class. For sampling, researchers used purposive sampling technique, namely sampling in the same way as the research object

In this study, the test type instrument was a test of students 'mathematical connection ability which consisted of 4 questions in the form of a description and a given time of 90 minutes and arranged based on the indicators of students' mathematical connection ability. The pre-test is to see the prerequisite material and the final test is to see the level of students' mathematical connection to the material. 
International Journal for Educational and Vocational Studies, 2 (11) (2020), 952-96o

Table 2. Rubric Assessment of students' mathematical connection abilities

\begin{tabular}{|c|c|c|}
\hline $\begin{array}{l}\text { Mathematical Connection } \\
\text { Capability Indicators }\end{array}$ & Student Responses to Given Questions & Scores \\
\hline \multirow{4}{*}{$\begin{array}{l}\text { Identify the relationships of } \\
\text { various representations of } \\
\text { mathematical concepts and } \\
\text { procedures }\end{array}$} & No answer & 0 \\
\hline & $\begin{array}{l}\text { Write down the relationship between mathematical concepts and procedures but is } \\
\text { wrong }\end{array}$ & 1 \\
\hline & $\begin{array}{l}\text { Write down the relationship between mathematical concepts and procedures but are } \\
\text { incomplete }\end{array}$ & 2 \\
\hline & $\begin{array}{l}\text { Able to identify the relationship between various representations of mathematical } \\
\text { concepts and procedures correctly }\end{array}$ & 3 \\
\hline \multirow{4}{*}{$\begin{array}{l}\text { Identify the relationship from } \\
\text { one procedure to another in } \\
\text { equivalent representations }\end{array}$} & No answer & 0 \\
\hline & $\begin{array}{l}\text { Writes the relationship from one procedure to another in an equivalent but incorrect } \\
\text { representation }\end{array}$ & 1 \\
\hline & $\begin{array}{l}\text { Writes the relationship from one procedure to another in an equivalent but } \\
\text { incomplete representation }\end{array}$ & 2 \\
\hline & $\begin{array}{l}\text { Be able to identify the relationship from one procedure to another in the equivalent } \\
\text { representation correctly }\end{array}$ & 3 \\
\hline \multirow{4}{*}{$\begin{array}{l}\text { Explain the application of } \\
\text { mathematical topics in } \\
\text { everyday life }\end{array}$} & No answer & 0 \\
\hline & Explaining the application of mathematical topics in everyday life but wrong & 1 \\
\hline & Explaining the application of mathematical topics in everyday life but incomplete & 2 \\
\hline & Able to explain the application of mathematical topics in everyday life correctly & 3 \\
\hline
\end{tabular}

Sources: Modified from Hendriana (2017: 86-94)

After the test scoring guidelines, a test analyst technique is needed to determine whether the test is classified as a good or bad test. The test analysis technique is in the form of validity, reliability, level of difficulty and differentiation.

\section{Results and Discussion}

This research was conducted to determine the application of the make a match type of cooperative model to improve the mathematical connection ability of students in the line and series material implemented at SMAN 1 Pintu Rime Gayo.

The following table describes the descriptive data of the pre test, post test and normality gain (N-gain) for the students' mathematical connection test. The results of the pre test, post test and N-gain scores can be seen in the appendix.

Table 3. Descriptive Statistical Data of Students' Mathematical Connection Ability

\begin{tabular}{|c|c|c|c|c|c|c|c|}
\hline \multirow{2}{*}{ Variable } & \multirow{2}{*}{ Statistics Data } & \multicolumn{3}{|c|}{ Experiment Class } & \multicolumn{3}{|c|}{ Control Class } \\
\hline & & PreTest & Posttest & $\mathrm{N}$-gain & PreTest & Posttest & N-gain \\
\hline \multirow{6}{*}{$\begin{array}{l}\text { Students' Mathematical } \\
\text { Connection Ability }\end{array}$} & $\mathrm{N}$ & 20 & 20 & 20 & 20 & 20 & 20 \\
\hline & $X \max$ & 7 & 12 & 1.00 & 8 & 12 & 1,00 \\
\hline & $X \min$ & 2 & 6 & 0.00 & 2 & 4 & 0,00 \\
\hline & $\bar{X}$ & 4,7 & 9,85 & 0,71 & 3,6 & 6,8 & 0,36 \\
\hline & $\mathrm{s}$ & 1,45 & 2,35 & 0,34 & 1,47 & 2,25 & 0,29 \\
\hline & $\%$ & 39,1 & 82,08 & & 30 & 56,6 & \\
\hline \multicolumn{8}{|c|}{ Max Scores $=12$} \\
\hline
\end{tabular}

From the data above, a comparison can be made for the average pre-test and post-test scores of the two classes in the following diagram:

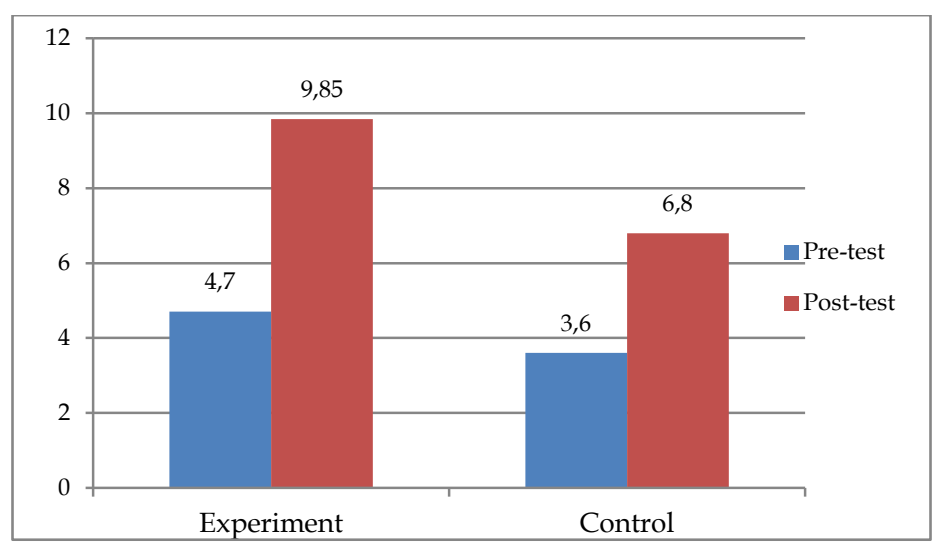

Figure 2. Average score of Pre-test and Post-test of Students' Mathematical Connection Ability 
Based on Table 3 and Figure 2 above, it can be seen that the average pre-test score for the mathematical connection ability of the experimental class and control class students was 4.7 and 3.6, respectively. While the average post test scores for the experimental class and the control class were 9.85 and 6.8 from the ideal maximum score 12. This shows that there are differences in the mathematical connection abilities of students in the experimental class and the control class before and after learning. The average post-test score of the experimental class and the control class each experienced an increase, where the average post-test of the experimental class who obtained the Make a Match cooperative learning model was higher than the post-test of the control class who received scientific learning. The average N-gain score of students' mathematical connection ability can be presented in the following table 4 .

Table 4. Average and N-gain Classification of Students' Mathematical Connection Ability

\begin{tabular}{ccc}
\hline Class & Averages of $\mathbf{N}$-gain & Classification of N-gain \\
\hline Experiment & 0,71 & Tinggi \\
\hline Control & 0,36 & Sedang \\
\hline
\end{tabular}

Based on the the table 4, a diagram of the comparison of the average N-gain can be made as follows.

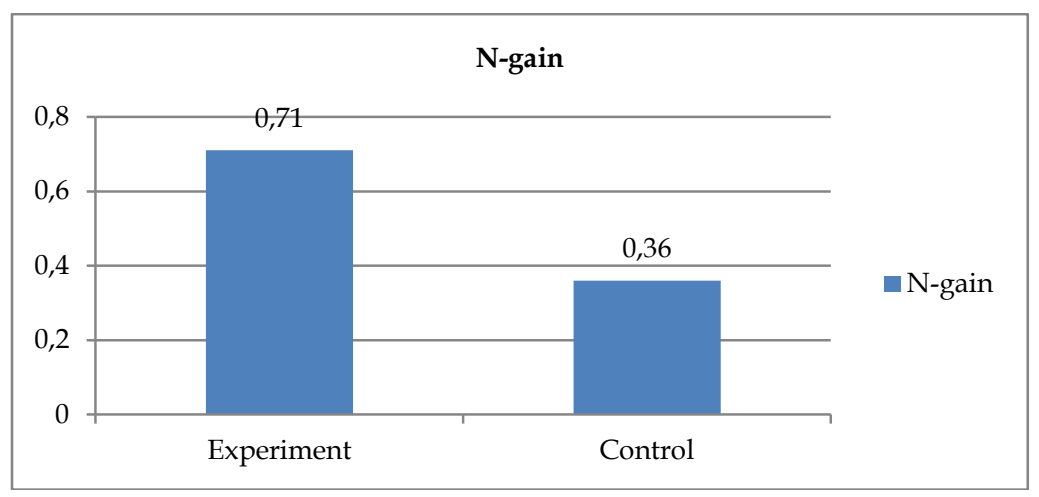

Figure 3. Average N-Gain of Students' Mathematical Connection Ability

Based on Table 3 and Figure 3 above, it can be seen that the average $\mathrm{N}$-gain in the experimental class is 0.71 and is in the high classification, while the average N-gain in the control class is 0.36 which is in the moderate classification. From these data it can be concluded that the increase in the mathematical connection ability of students in the experimental class, namely the class that received the make a match cooperative learning model was higher than the control class who received scientific learning. This shows that there is an increase between the two classes, namely the experimental class has a higher increase than the control class. The normality test in this study was the Shapiro-Wilk technique where decision making was used with a significant level of $\alpha=0.05$. If the significant value $<0.05$ then the data is not normally distributed or $\mathrm{H}_{0}$ is rejected, whereas if the significant value is $\geq 0.05$ then the data is normally distributed or $\mathrm{H}_{0}$ is accepted. The results of the normality test for the N-gain score are shown in the table 5.

Table 5. Results of the Data Normality Test on Students' Mathematical Connection Skills

\begin{tabular}{|c|c|c|c|c|c|c|}
\hline \multirow{3}{*}{ N-gain } & \multirow{2}{*}{ Class } & \multicolumn{3}{|c|}{ Shapiro-Wilk } & \multirow{2}{*}{ Conclusion } & \multirow{2}{*}{ Description } \\
\hline & & Statistic & $\mathrm{df}$ & Sig. & & \\
\hline & Experiment & 0,8 & 20 & 0,001 & $\mathrm{H}_{0}$ Rejected & Not Normally \\
\hline & Control & 0,894 & 20 & 0,031 & $\mathrm{H}_{0}$ Rejected & Not Normally \\
\hline
\end{tabular}
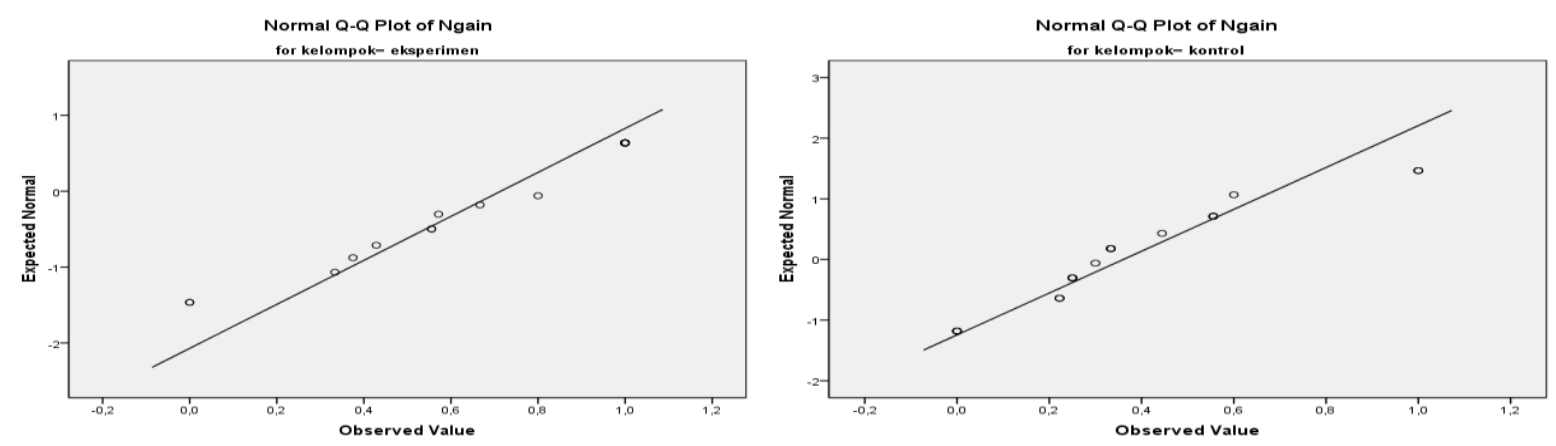

Figure 4. Graph of Normality Test Data Results N-gain Score Students' Mathematical Connection Ability 
Based on Figure 4, it shows that the Q-Q plot of the N-Gain score data for the experimental class and control class is not normally distributed. This can be seen from the points that are approaching, there are some points that spread far from the direction of the line or do not follow the diagonal line. The points in the graph represent the state of the data being tested and because the data is not normally distributed, the test used for hypothesis making is using the non-parametric test calculation (Mann-Whitney U-Test). The hypothesis in this study is that the students 'mathematical connection ability through the make a match type of cooperative learning model is better than the students' mathematical connection ability through the scientific learning model on the class XI class of SMAN 1 Pintu Rime Gayo material. The testing is carried out based on the following statistical hypothesis:

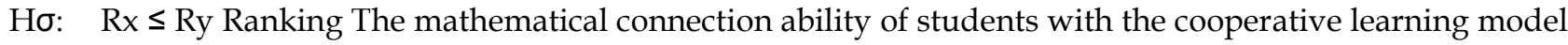
make a match type is not better than the scientific learning model in the mathematics sequence and series material for class XI of SMAN 1 Pintu Rime Gayo.

Ha: $\quad R x>$ Ry Ranking The mathematical connection ability of students with the cooperative learning model make a match type is better than scientific learning in class XI class XI material at SMAN 1 Pintu Rime Gayo.

\section{Information:}

$\mathrm{Rx}=\mathrm{N}$-gain ranking of mathematical connection ability of students who get the make a match cooperative learning model.

Ry $=\mathrm{N}$-gain ranking of mathematical connection ability of students who receive scientific learning model.

Where the test criteria are:

If the Sig (p-value) $<\alpha(\alpha=0.05)$, then H0 is rejected, that is, the research results have increased.

If the Sig (p-value) $\geq \alpha(\alpha=0.05)$, then H0 is accepted, that is, there is no improvement in the research results.

Table 6. Data Comparison of Rank N-gain Test Results of Students' Mathematical Connection Ability

Test Statistics ${ }^{b}$

\begin{tabular}{lr}
\hline & Ngain \\
\hline Mann-Whitney U & 84,500 \\
\hline Wilcoxon W & 294,500 \\
\hline$Z$ & $-3,178$ \\
\hline Asymp. Sig. (2-tailed) &, 001 \\
\hline Exact Sig. [2*(1-tailed Sig.)] &, $001^{\mathrm{a}}$ \\
\hline a. Not corrected for ties. & \\
b. Grouping Variable: Groups &
\end{tabular}

Based on the the results of the Mann-Whitney U-Test above, it can be concluded that the Asymp value. Sig (2-tailed) is 0.001. Because sig $<\alpha=0.05$ then Ho is rejected, thus Ha is accepted and it can be concluded that there is an increase in students' mathematical connection skills taught through the make a match cooperative model is better than the mathematical connection ability of students taught through scientific learning models. significant.

\section{Discussion}

This study aims to see the increase in the mathematical connection ability of students who get the make a match cooperative learning model better than the mathematical connection ability of students who get scientific learning in line and series material. Based on the research results, it shows that the analysis obtained in testing this hypothesis turns out that the mathematical connection ability of students taught through the make a match cooperative model is better than those taught by scientific learning at SMAN 1 Pintu Rime Gayo. This is in accordance with the results of research data which show that the average score for students' mathematical connection ability can also be seen from the average value obtained during the learning process. In the experimental class the average n-gain value obtained by students was 0.715 , while in the control class the average n-gain value obtained by students was 0.36 , of the two average values, there was a clear difference. In this study, the students' mathematical connection ability was seen from the pre-test before being given the treatment and the post-test scores that were carried out after being given the treatment. The test questions are in the form of an essay consisting of 4 questions, each of which has a maximum score of 3 . There are three indicators measured in this study, namely identifying the relationship between various representations of mathematical concepts and procedures, identifying the relationship of one procedure to another in equivalent representation and explaining the application of the topic. mathematics in everyday life. The following is an example of a student's pretest and posttest questions and answers based on the student's mathematical connection ability indicator, namely explaining the application 
of mathematical topics in everyday life.

4. Salah satu kedai kopi mendapatkan keuntungan setiap bulannya bertambah menjadi dua kali lipat dari keuntungan bulan sebelumnya. Jika keuntungan bulan pertama adalah Rp. 600.000 maka keuntungan kedai kopi tersebut pada bulan keenam adalah...

Figure 5. Mathematical Connection Ability Test Questions for Students

The picture above is a question of student's mathematical connection ability number 4 . Where students must be able to apply mathematical topics in their daily life to the above questions, students are required to be able to determine the profit of a coffee shop in the sixth month, whose profits are doubled every month.

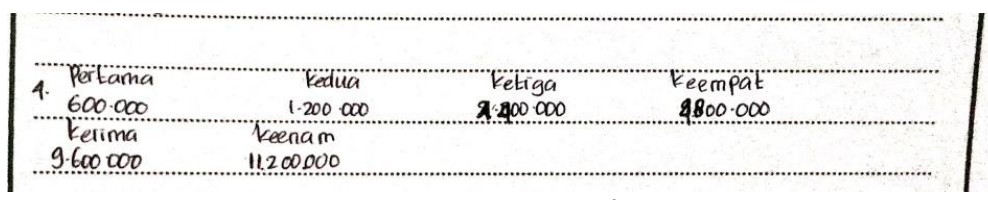

Figure 6. Answer of Pre-Test

The above is one of the students 'answers when taking the pre-test, where in the picture above, it can be seen that the students' mathematical connection ability is still low, and students have not been able to apply mathematical topics in everyday life. This can also be seen from the 20 students who took the pre-test in the experimental class, there were no students who could answer correctly, 1 student answered but the answers were still incomplete, 9 students answered incorrectly and 10 students did not answer at all while in the control class of 20 students There were no students who took the pre test who could answer correctly, 2 students answered but the answers were still incomplete, 8 students answered incorrectly and 10 students did not answer at all.

$\begin{aligned} & \text { 4. } D_{K}=a=600000 \\ & r=2 \\ & n=6 \\ & \text { Penyelesai an: } \\ & U_{n}=a_{r}{ }^{n-1} \\ & U_{6}=600 \cdot 000 \cdot 2^{6-1} \\ &=600 \cdot 000 \cdot 2^{5} \\ &=600 \cdot 000-32 \\ &=19.200 \cdot 000 \\ & \text { Jadi Keuntungan kedai kopi tersebut pada bulan } \\ & \text { keenam adalah } 19 \cdot 200 \cdot 000\end{aligned}$

Figure 7. Answer of Post-Test of Experiment Class

Based on the results of the post-test answers above, it shows that the mathematical connection ability of students in the experimental class has increased compared to the pre-test. Where students have been able to apply mathematical topics in everyday life and the results are correct. This post test was attended by 20 students in the experimental class, 13 students were able to apply mathematical topics in everyday life and the results of the answers were correct, 5 students were able to apply mathematical topics in everyday life but the answers were still incomplete, 1 student answered incorrectly and 1 students didn't answer at all. If we compare the students 'pretest answers with the students' post-test answers in the experimental class, at the time of the post-test the students were able to apply mathematical topics in everyday life and the results of the answers were correct, it's just that some students were still wrong so their answers were wrong.

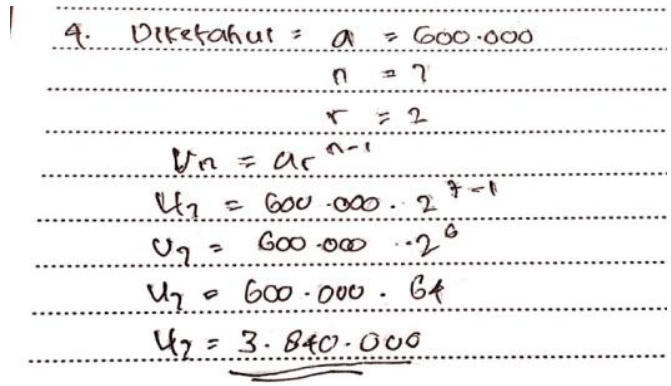

Figure 8. Answer of Post-Test of Control Class 
Based on the results of the post test above, it shows that the mathematical connection ability of students in the control class has increased slightly compared to the pre-test. However, there were still many students who made mistakes so that when they answered the questions there were still many who answered wrong and the answers were incomplete. This post test was attended by 20 students in the control class, only 3 students were able to apply mathematical topics in their daily life and the results were correct, 6 students were able to apply mathematical topics in daily life but the answers were still incomplete, 4 students answered incorrectly and 7 students did not answer at all. The improvement in the experimental class by applying the cooperative learning model make a match type is better than the control class with scientific learning, this can be seen in the number of students who are able to answer correctly in the experimental class more than the control class. Based on the above discussion, it can be seen that both the cooperative learning model make a match type and scientific learning can improve students' mathematical connection skills in the sequence and series material. When given the pre-test and post-test, both learning were able to improve students' mathematical connection skills, but in the experimental class that used the cooperative learning model make a match, students seemed to participate more in learning because students had to be individually responsible for finding pairs of cards and solving problems even though there were several students who do not respond to the learning process.

\section{Conclusion}

Based on the results of research that has been conducted by researchers, it is known that the application of the make a match type of cooperative learning model can improve students 'mathematical connection skills in the line and series material where the researcher applies three indicators of students' mathematical connection abilities, namely Identifying the relationship between various representations of mathematical concepts and procedures, identifying relationships one procedure to another in equivalent representation and explaining the application of mathematical topics in everyday life. Based on the results of statistical analysis data, it can be seen that the average pre-test score for the mathematical connection ability of the experimental class and control class students was 4.7 and 3.6, respectively. While the average post-test scores for the experimental class and control class were 9.85 and 6.8 from the ideal maximum score 12 . This shows that there is an increase in each class, both the experimental class and the control class. For the average Ngain, it was obtained 0.71 for the high classification experiment class and 0.36 for the average $\mathrm{N}$-gain in the control class with moderate classification. From these data it can be concluded that the increase in the mathematical connection ability of students in the experimental class, namely the class that received the make a match cooperative learning model was higher than the control class who received scientific learning. Based on the hypothesis test, the Sig value is 0.001 . Because sig $<\alpha=0.05$ then Ho is rejected, thus Ha is accepted and it can be concluded that there is an increase in the mathematical connection ability of students taught through the make a match cooperative model is better than the mathematical connection ability of students taught through the scientific learning model.

\section{References}

Haety, N. I dan Mulyana, E. (2013). Pengaruh Model Pembelajaran Matematika Knisley Terhadap Peningkatan Kemampuan Koneksi Matematis Siswa SMA (Penelitian Kuasi Eksperimen Terhadap Siswa Kelas XI di Salah Satu SMA Negeri). Jurnal Online Pendidikan Matematika Kontemporer, Volume 1, No.1: 1- 8.

Hake, R. R. (1999). Analyzing Change/gain Scores. (http://www.physics.indiana.edu/nsdi/AnalyzingChange-Gain.pdf) Diakses pada tanggal 20 Agustus 2020.

Hendriana, H dan Soemarmo, U. (2016). Penilaian Pembelajaran Matematika. Bandung: PT Refika Aditama.

Hendriana, H., Rohaeti, E.E dan Soemarmo, U. (2017). Hard Skills dan Soft Skills Matematika Siswa. Bandung: Refika Aditama.

Herlikano, M. A dan Sujadi. (2017). Peningkatan Keaktifan dan Hasil Belajar Matematika Menggunakan Make a Match siswa kelas VIII A SMP N 2 Temon. Union: Jurnal Pendidikan Indonesia, Volume 5, No. 2: $121-128$

Kadir dan Mayjen. (2013). Mathematical Communication Skills of Junior Secondary Scholl Students in Coastal Area. Jurnal Teknologi: Social Sciences.

Lestari, K.E dan Mokhammad R.Y. (2018). Penelitian Pendidikan Indonesia. Bandung: PT Refika Aditama.

NCTM. (2000). Priciples and Standards for School Mathematic. Reston, VA: NCTM

Puteri, J. W dan Riwayati, S. (2017). Kemampuan Koneksi Matematis Siswa Pada Model Pembelajaran Connected Mathematics Project (CMP). FIBONACCI Jurnal Pendidikan Matematika dan Matematika, Volume 3, No. 2: 161-168. 
Romli, M. (2016). Profil Koneksi Matematis siswa Perempuan SMA dengan kemampuan Matematika Tinggi dalam menyelesaikan masalah matematika". MUST: Journal of Mathematis Education, Sciense and technology, Volume 1, No. 2: 144-163.

Rusman. (2012). Model-model pembelajaran Mengembangkan Profesionalisme guru. Bandung: Rajawali Pers.

Sanjaya, W. 2011. Strategi Pembelajaran Berorientasi Standar Proses Pendidikan. Jakarta: Kencana Prenada Media Group.

Sugiyono. (2017). Metode Penelitian Pendidikan Pendekatan Kuantitatif,Kualitatif, dan RED. Bandung: Alfabeta.

Suryabrata, S. (2013). Metodologi Penelitian. Jakarta: Rajawali Pers. 